\title{
Türk Bankacllk Sektöründe Finansal Performans Ölçmede TOPSIS Yönteminin Kullanımı: Katılım Bankaları Üzerine Bir Uygulama
}

Tuba ÖZKAN' ${ }^{1}$

Makale Gönderim Tarihi: 16.05.2019

Makale Kabul Tarihi: 16.03.2020

\section{Öz}

Bu çalıșmada, Türkiye'de faaliyet gösteren faizsiz bankacılığı ifade eden katılım bankalarının 2016-2018 dönemi için etkinlik ve verimlilik oranları temel alınarak Çok Kriterli Karar Verme Yöntemleri'nden TOPSIS (Technique for Order Preference by Similarity to Ideal Solution) yöntemine göre performans sıralamasının yapılması hedeflenmiștir. 2016-2018 döneminde sürekli faaliyet gösteren 5 katılım bankasının performans düzeyleri karșılaștırmalı olarak analiz edilmiș ve analiz sonucunda en iyi performansı gösteren bankanın Türkiye Finans Katılım Bankası A.Ș. olduğu tespit edilmiștir.

Anahtar Kelimeler: Katılım Bankacılığı, Bankacılık Sektörü, TOPSIS Yöntemi, Performans Analizi.

JEL Kodları: D57, G21, M21.

\section{The Use of TOPSIS Method in Financial Performance Measurement in Turkish Banking Sector: An Application on Participation Banks}

\section{Abstract}

In this study, it was aimed to make performance ranking according to TOPSIS (Technique for Order Preference by Similarity to Ideal Solution) method which is one of the Multi-Criteria Decision Making Methods based on efficiency and productivity ratios of participation banks

1 Dr. Öğrt. Üyesi, Atatürk Üniversitesi, Oltu Beșeri ve Sosyal Bilimler Fakültesi, Bankacılık ve Finans Bölümü, tuba.ozkan@atauni.edu.tr, Orcid ID: 0000-0001-9510-2963. 
which means interest-free banking for the 2016-2018 period in Turkey. Performance levels of 5 participation banks operating continuously during the period of 2016-2018 were analyzed comparatively and Turkey Finans Participation Bank Inc. was found to be the bank showing the best performance as a result of the analysis.

Key Words: Participation Banking, Banking Sector, TOPSIS Method, Performance Analysis.

JEL Codes: D57, G21, M21.

\section{Giriș}

"İslami finans", "İslami bankacılık" ya da "Faizsiz bankacılık" olarak adlandırılan katılım bankaları, faize karșı hassas olan Müslüman toplumların atıl fonlarını ekonomiye kazandırmak amacıyla kurulmuș olup; günümüzde hem Müslüman hem de Müslüman olmayan toplumlara hizmet verebilecek konuma gelmișlerdir.

Dünya literatürüne İslami bankacılık adı alında, 1960'lı yıllarda giren katılım bankacılığının Türkiye'ye giriși, 1983 yılına tekabül etmektedir. 1983 yılında çıkarılan yasa gereği, Türkiye'de İslami bankalar "Özel Finans Kurumları" adıyla kurulmuștur. 1985'te Albaraka Türk ve Faisal Finans Kurumları İslami esaslara göre kurulmuș ilk kurumlardır. Özel Finans Kurumları ismi, 2005 yılında yapılan son değișiklik ile İslami bankacılık ișlemlerini anlatmakta yetersiz kaldığı için "Katılım Bankaları" olarak değiștirilmiștir. Türkiye'de katılım bankaları farklı așamaları geçerek gelișmesini sürdürmektedirler (Pehlivan, 2016, s. 304-305).

Türkiye'deki Katılım Bankacılığı Sektörünün 2018 yılı verileri doğrultusunda bankacılık piyasasından aldığı pay toplanan fonlarda \%6,7, kullandırılan fonlarda \%5, 1 ve aktif büyüklügünde \%5,3'e yükselmiștir. Katılım bankalarının özkaynak toplamı \%23'lük artıșla milyon TL'ye, net dönem kar ise \%34, 1 artıșla 2.123 milyon TL'ye yükselmiștir. 2018 yılsonu rakamlarına göre katılım bankalarının toplam șube sayısı 1.122'ye ulașarak bankacılık sektörü toplam șube ağının yaklașık \%8'ini olușturmuștur. Katılım bankalarının yılsonu itibariyle toplam çalıșan sayısı 15.654 kișiye ulașarak bir önceki yıla göre \%4,2 artarak 15.654 kișiye ulașmıștır (TKBB, 2018, s. 14-15).

Bankaların performans gidișatını görebilmek için bankaların faaliyetlerinin ne kadar etkin olduğunu ölçmek gerekir. Bankacılık ișlem- 
lerinde etkinlik, bankaların topladığı mevduatların maksimum kazanç sağlanabileceği yatııılarda değerlendirilmesi olarak tanımlanabilir. Bu durumun gerçekleșebilmesi için ise bankaların kaynaklarının kullanımını minimum düzeyde tutmaları gerekmektedir. Bu çalıșma, bankalar için en önemli konuların bașında gelen karlılık ve etkinlik unsurlarını, katılım bankaları bazında karșılaștırmalı olarak incelemektedir.

Bu çalıșmada, Türkiye'de faaliyet gösteren Katılım bankalarının 20016 - 2018 yılları arasındaki etkinlik ve verimlilik oranları temel alınarak TOPSIS yöntemine göre performans sıralamasının yapılması hedeflenmiștir. Söz konusu dönemde aralıksız faaliyette bulunan bankalar (Albaraka Türk, Kuveyt Türk, Türkiye Finans, Ziraat ve Vakıf Katılım Bankaları) incelemeye alınmıștır.

\section{Literatür}

Literatürde ulusal ve uluslararası alanda TOPSIS yöntemi kullanılarak bankacılık sektöründe birçok çalıșma yapılmasına rağmen; katılım bankaları ile ilgili yapılan çalıșmalar az sayıdadır.

Yayar ve Baykara (2012), 2005-201 1 dönemleri arasındaki çeșitli kriterlere göre 12 adet rasyo kullanarak 4 adet katılım bankasının kaynaklarının verimli ve etkin kullanılıp kullanılmamasını TOPSIS yöntemiyle analiz etmișlerdir. Yapılan araștırma sonucunda Bank Asya en verimli, Albaraka Türk en etkin banka olarak tespit edilmiștir.

Șamiloğlu vd. (2013), Türk bankacilık sektöründe faaliyet gösteren 4 katılım ve 4 ticari banka olmak üzere toplamda 8 bankanın 2003-2011 dönemindeki karlılık performanslarını karșılaștırmıșlardır. Ticari bankaların ve katılım bankalarının bilanço ve gelir tablolarındaki verilerle elde edilen rasyolar aracılı̆ı̆ıla performans puanları TOPSIS yöntemiyle hesaplanmıștır. Araștırma sonucunda ticari bankalara nazaran katılım bankalarının daha karlı oldukları ve performanslarının daha yüksek olduğu görülmüștür.

Bașka bir çalıșmada Bağcı (2013), 2003-2011 yılları arasında katılım bankaları ile ticari bankaların TOPSIS yöntemiyle karlılık performanslarını ölçmüș ve ticari bankalardan ziyade katılım bankalarının daha yüksek performansa sahip ve daha karlı olduklarını belirlemiștir.

Wanke, Azad ve Barros (2016) çalıșmalarında, Malezya İslami bankalarının etkinlikleri TOPSIS ile bankacilıkta en sık kullanılan performans göstergeleri kullanılarak analiz edilmiș ve ardından sinir ağları modeli ile etkin bir tahmin yeteneği olan bir bankacılık performans ölçü- 
mü tahminleme metodu önerilmiștir. Çalıșmada kullanılan 16 bankanın 2009-2013 yılları verileri yıllık faaliyet raporlarından elde edilmiștir. TOPSIS'te, en ideal durumlar, en az harcama ile en çok gelir-en iyi finansal performans göstergesi veren durumlar olarak seçilerek, 16 banka için verimlilik sıralaması olușturulmuștur.

Esmer ve Bağcı (2016), 2005-2014 yılları arasında Türk bankacılık sektöründeki 4 katılım bankasının finansal performansını TOPSIS metodunu kullanarak ölçmeye çalıșmıșlardır. Hangi katılım bankasının hangi yılda daha yüksek finansal performans gösterdiği TOPSIS metodu yardımıyla bulunarak bu sonuçlara ait bir takım yorumlarda bulunulmuștur.

Aras, Tezcan ve Furtuna (2016) çalıșmalarında, Türkiye'deki geleneksel bankalar ile katılım bankalarının sürdürülebilirlik performanslarını karșılaștırmıșlardır. Entropi ile sürdürülebilirlik göstergelerinin ağırlıklarını elde ettikten sonra, bankaların kurumsal sürdürülebilirlik performans puanlarını TOPSIS yöntemini kullanarak hesaplanmıșlardır. Çalıșma sonucunda, sürdürülebilirlik boyutları bazında geleneksel bankacılık ve katılım bankacılığı arasında performans puanlarında belirgin bir fark olmadığını tespit etmișlerdir.

Wanke, Hassan ve Gaviao (2017), $2010-2013$ yılları arasında 88 ASEAN bankasının göreceli verimliliğini TOPSIS yöntemi ile değerlendirmișlerdir. Değerlendirme sonucunda, İslami ilkelerin bankaların verimliliği üzerinde olumlu etkisi olduğu sonucuna ulașmıșlardır.

Alsu, Tașdemir ve Kallo (2018) çalıșmalarında, 2009 ile 2015 yılları arasında TOPSIS yöntemini kullanarak Birleșik Arap Emirlikleri, Ürdün, Suudi Arabistan, Katar, Kuveyt ve Türkiye'de faaliyet gösteren toplam 18 katılım bankasının finansal performanslarını incelenmișlerdir. Çalıșma sonucunda, Katar ve Suudi Arabistan'daki katılım bankalarının üst sıralarda yer alarak daha iyi performans sergilediği gözlemlenmiștir. Türk katılım bankalarının ise orta sıralarda yer aldığı ve bu bankalar arasında performans sonuçlarına göre, Albaraka Türk katılım bankasının diğerlerine oranla daha iyi performans sergilediği görülmüștür.

Abdi (2018) çalıșmasında, 2007 - 2016 yılları arasında Türkiye'de aralıksız faaliyette bulunan 3 katılım bankasının etkinlik ve verimlilik oranlarını temel alarak Bulanık TOPSIS ve Shannon Entropi yöntemlerine göre performans sıralamasını yapmıștır. Yaptığı sıralama sonuçlarına göre, etkinlik ve verimlilik oranları bağlamında ilk iki sıradaki katılım bankaları yer değiștirirken son sıradaki banka hep Kuveył Türk olmuștur. 
Kendirli vd. (2019), Türkiye'de faaliyet gösteren 3 katılım ve 10 ticari banka olmak üzere toplam 13 bankanın kriz öncesi dönemi (20052008), kriz dönemi (2008-2011) ve kriz sonrası dönemi (2011-2015) verileri kullanılarak TOPSIS yöntemiyle mali performanslarını dönem dönem analiz etmișlerdir. Yapılan analiz çalıșması sonucunda diğer ülkelere bakılarak Türkiye'nin 2001 krizinde yașanan olumsuzluklardan sonra önlemlerini almıș olmasından dolayı beklenenden daha iyi performans sergilediği belirtilmiștir.

\section{Araștırmanın Amacı ve Kapsamı}

Araștırmanın temel amacı, Türkiye'de faaliyet gösteren katılım bankalarının TOPSIS yöntemi ile finansal performanslarının değerlendirilmesi ve birbirleriyle karșılaștırılmasıdır. Çalıșmaya, 2016-2018 yıllarını kapsayacak șekilde, 5 katılım bankası dahil edilmiștir. Analiz kapsamında yer alan bankalar așağıda Tablo 1'de gösterilmektedir.

Tablo 1. Analiz Kapsamında Yer Alan Bankalar

\begin{tabular}{|c|l|l|}
\hline & İșlem Kodu & Banka \\
\hline $\mathbf{1}$ & ALBARAKA & Albaraka Türk Katıım Bankası A.Ș. \\
\hline $\mathbf{2}$ & KUVEYT & Kuveył Türk Katılım Bankası A.Ș. \\
\hline $\mathbf{3}$ & FiNANS & Türkiye Finans Katılım Bankası A.Ș. \\
\hline $\mathbf{4}$ & VAKIF & Vakıf Katııım Bankası A.Ș. \\
\hline $\mathbf{5}$ & ZIRAAT & Ziraat Katılım Bankası A.Ș. \\
\hline
\end{tabular}

\section{Araștırmanın Verileri ve Yöntemi}

TOPSIS yöntemi kullanılarak bankaların finansal performansları, belirlenmeye çalıșılmıș ve modelin çözümünde Microsoft Office Excel paket programından yararlanılmıștır. Yılsonu verilerinin kullanıldığı analizde, veriler Türkiye Katılım Bankaları Birliği internet sitesinde yer alan bilanço ve gelir tablosu verilerine dayalı analiz ve raporlardan elde edilerek hazırlanmıștır.

Așağıda Tablo 2' de yer alan 8 finansal oran, çalıșmada kullanılmak üzere bankaların borç ödeme güçleri, finansal yapıları, varlıklarının etkin kullanımı ve karlılıkları hakkında bilgi verebilecek nitelikteki oranlar arasından seçilmiș ve bu oranların toplamları 1 olacak șekilde önem seviyelerine göre ağırlıkları ağırlıkları olușturulmuștur. 
Tablo 2. Çalıșmada Kullanılan Finansal Oranlar ve Ağırlıkları

\begin{tabular}{|l|l|c|c|}
\hline & Finansal Rasyolar & Sembolü & $\begin{array}{c}\text { Ağırlıklar } \\
\text { (W) }\end{array}$ \\
\hline $\begin{array}{l}\text { Sermaye Ye- } \\
\text { terliliği }\end{array}$ & Özkaynaklar / Toplam Aktifler & 01 & 0,10 \\
\hline \multirow{2}{*}{ Aktif Kalitesi } & Toplam Krediler ve Alacaklar/ Toplam Aktifler & 02 & 0,10 \\
\cline { 2 - 4 } & Duran Aktifler / Toplam Aktifler & O3 & 0,10 \\
\hline Likidite & Likit Aktifler / Toplam Aktifler & O4 & 0,10 \\
\hline \multirow{2}{*}{ Karlıık } & Ortalama Aktif Karlılığı & O5 & 0,15 \\
\cline { 2 - 4 } & Ortalama Özkaynak Karlılığı & O6 & 0,15 \\
\hline $\begin{array}{l}\text { Gelir-Gider } \\
\text { Yapısı }\end{array}$ & Özel Karșılıklar Sonrası Net Kar Payı / Toplam Aktifler & O7 & 0,15 \\
\cline { 2 - 4 } & $\begin{array}{l}\text { Özel Karșılıklar Sonrası Net Kar Payı / Toplam Faaliyet } \\
\text { Gelirleri }\end{array}$ & O8 & 0,15 \\
\hline
\end{tabular}

\subsection{TOPSIS Analizi}

TOPSIS yöntemi, ișletmelerin günümüzün yoğun rekabet ortamında performanslarını değerlendirmede ve karșılaștırmada, çok kriterli karar verme problemlerinin çözümünde çoklu finansal oranları göz önüne alarak kullanılmaktadır.

TOPSIS yönteminin temel mantığı, negatif ve pozitif ideal çözümü belirlemeye dayanmaktadır. Bu yöntemde alternatiflerin sıralanması ideal çözüme göreceli olarak yakınlık ile belirlenir. Maliyet kriterini minimize edip; fayda kriterini maksimize eden çözüm pozitif ideal çözümdür. Maliyet kriterini maksimize edip; fayda kriterini minimize eden çözüm ise negatif ideal çözümdür. En uygun seçenek ise, negatif ideal çözüme en uzak ve ideal çözüme en yakın olan seçenektir. (Wu, Lin ve Tsai, 2008 , s. 256).

TOPSIS yöntemi așağıdaki adımları takip etmektedir (Cağlıyan vd, 2015, s. 45-47).

\section{Adım 1: Karar Matrisinin Olușturulması (A)}

Karar matrisinin sütunlarında karar vermekte kullanılan değerlendirme kriterleri yer alırken, karar matrisinin satırlarında üstünlükleri sıralanmak istenen karar noktaları yer almaktadır. Karar verici tarafından olușturulan A matrisi bașlangıç matrisidir. Karar matrisinin biçimi așağıdaki gibidir. 


$$
A_{i j}=\left[\begin{array}{cccc}
a_{11} & a_{12} & \ldots & a_{1 n} \\
a_{21} & a_{22} & \ldots & a_{2 n} \\
\cdot & & & \cdot \\
\cdot & & & \cdot \\
\cdot & & & \cdot \\
a_{m 1} & a_{m 2} & \ldots & a_{m n}
\end{array}\right]
$$

$A_{i j}$ matrisinde $\mathrm{n}$ değerlendirme faktörü sayısını, $\mathrm{m}$ karar nokłası sayısını verir.

Çalıșmamızda karar matrisinde 2016-2018 yılları itibariyle Türk katılım bankaları alternatifler (n), bankaların finansal performans oranları ise kriterler (m) olarak değerlendirilmiștir.

\section{Adım 2: Normalize Edilmiș Karar Matrisinin Olușturulması (R)}

Normalize karar matrisinin bir diğer adı da standart karar matrisidir. Normalize edilmiș karar matrisinin (R) olușturulduğu sırada, A matrisi içerisinde yer alan elemanlarından yararlanılmaktadır. Farklı ölçümleri tașıyan kriterlerin aynı ölçü birimine dönüștürülmesi normalize edilmenin amacıdır. Așağıdaki formül yardımıyla normalize edilmenin hesaplanması geçekleștirilmektedir:

$$
r_{i j}=\frac{a_{i j}}{\sqrt{\sum_{k=1}^{m} a_{k j}^{2}}}
$$$$
i=1 \ldots, \mathrm{m} ; \quad i=1, \ldots, \mathrm{n}
$$

Așağıda $R$ matrisinin elde edilme șekli verilmiștir:

$$
R_{i j}=\left[\begin{array}{cccc}
r_{11} & r_{12} & \ldots & r_{1 n} \\
r_{21} & r_{22} & \ldots & r_{2 n} \\
\cdot & & & \cdot \\
\cdot & & & \cdot \\
\cdot & & & \cdot \\
r_{m 1} & r_{m 2} & \ldots & r_{m n}
\end{array}\right]
$$




\section{Adım 3: Ağırlıklı Standart Karar Matrisinin Olușturulması (V)}

Normalize edilmiș karar matrisinin elemanları, bu adımda kriterlerin tașıdığı önemliliğe göre ağırlıklandırılmaktadır. Ağırlılığın değeri $\left(W_{i}\right)$ de kriterin tașıdığı önemliliğe göre belirlenmektedir.

$$
\left(\sum_{i=1}^{n} w_{i}=1\right)
$$

Ağırlıkların belirlenmesinden sonra, $\mathrm{R}$ matrisinin her sütundaki elemanlarla ilgili W değeri ile çarpılıp ağırlıklandırılmıș normalize edilmiș karar matrisi $\left(V_{i j}\right)$ olușturulmaktadır. Matris $V$, așağıdaki gibi gösterilmektedir:

$$
\begin{aligned}
\mathrm{V}_{\mathrm{ij}} & =\mathrm{w}_{\mathrm{i} \cdot \mathrm{r}_{\mathrm{ij}}} \\
V_{i j} & =\left[\begin{array}{cccc}
w_{1} r_{11} & w_{2} r_{12} & \ldots & w_{n} r_{1 n} \\
w_{1} r_{21} & w_{2} r_{22} & \ldots & w_{n} r_{2 n} \\
\cdot & & & \cdot \\
\cdot & & & \cdot \\
\cdot & & & \cdot \\
w_{1} r_{m 1} & w_{2} r_{m 2} & \ldots & w_{n} r_{m n}
\end{array}\right]
\end{aligned}
$$

\section{Adım 4: İdeal $\left(A^{*}\right)$ ve Negatif İdeal $\left(A^{-}\right)$Çözümlerin Olușturul- ması}

Negatif ideal çözümün en kötü performans değerlerini içerirken, ideal çözüm normalize edilmiș karar matrisindeki optimal performans değerlerini içermektedir. Așağıdaki formül ideal çözümün setinin hesaplanması için kullanılmaktadır:

$$
\begin{aligned}
A^{*} & \left.=\left\{\max _{i} v_{i j} \mid j \in J\right), \min _{i} v_{i j} \mid j \in J^{\prime}\right\} \text { formülünden hesaplanan set } \\
A^{*} & =\left\{v_{1}^{*}, v_{2}^{*}, \ldots, v_{n}^{*}\right\} \text { gibi gösterilmektedir. }
\end{aligned}
$$

Negatif ideal çözüm setinin hesaplanması așağıdaki formül ile gösterilmektedir;

$$
\begin{aligned}
& A^{-}=\left\{\min _{i} v_{i j} \mid j \in J\right),\left(\max _{i} v_{i j} \mid j \in J^{\prime}\right\} \text { ile hesaplanan seti } \\
& A^{-}=\left\{v_{1}^{-}, v_{2}^{-}, \ldots, v_{n}^{-}\right\} \text {gibi gösterilmektedir. }
\end{aligned}
$$


$J$ fayda (maksimizasyon), $J^{\prime}$ ise kayıp (minimizasyon) değerini göstermektedir.

\section{Adım 5: Ayırım Kriterlerinin Hesaplanması}

Bu adımda, Öklid Mesafe Yaklașımı ayrım kriterlerini hesaplamak için uygulanmaktadır. Her alternatif ile ideal çözüm arasındaki mesafe așağıdaki gibidir:

$$
S_{i}^{*}=\sqrt{\sum_{j=1}^{n}\left(v_{i j}-v_{j}^{*}\right)^{2}} \quad i=1, \ldots ., \mathrm{m}
$$

Benzer șekilde her alternatif ile negatif ideal çözüm arasındaki uzaklığı hesaplanırken așağıdaki formül ile bulunmaktadır

$$
S_{i}^{-}=\sqrt{\sum_{j=1}^{n}\left(v_{i j}-v_{j}^{-}\right)^{2}} \quad i=1, \ldots, \ldots, \mathrm{m}
$$

Hesaplanacak olan $S_{i}^{*}$ ve $S_{i}^{-}$sayısı doğal olarak karar noktası sayısı kadar olacaktır.

\section{Adım 6: İdeal Çözüme Göreli Yakınlığın Hesaplanması}

Önceki adımda hesaplanan mesafe ayrımlarından yararlanılarak her karar nokłası için ideal çözüme yakınlık $\left(C_{i}^{*}\right)$ hesaplanmaktadır. Karar noktalarının ideal çözüme yakınlığının hesaplanması așağıdaki formül ile gösterilmektedir.

$$
C_{i}^{*}=\frac{S_{i}^{-}}{S_{i}^{-}+S_{i}^{*}} \quad i=1, \ldots \ldots, \mathrm{m}
$$

$C_{i}^{*}$ değeri 0 ile 1 arasında $\left(0 \leq C_{i}^{*} \leq 1\right)$ bir değer almaktadır. $C_{i}^{*}=1$ olduğunda uygun alternatifin pozitif ideal çözümün noktasında olduğunu ve ilgili alternatifinin $C_{i}^{*}=0$ olduğunu ifade etmektedir. Birçok literatürde son olarak yedinci adım diye adlandırılan adım tercih sıralamasıdır. $C_{i}^{*}$ değerlerinin değeri en küçükten en büyüğe doğru artmaktadır. $C_{i}^{*}$ değeri en yüksek olan alternatif en iyi, en düșük olan alternatif ise en kötü alternatif olarak tanımlanır.

\subsection{Bulgular ve Değerlendirilmesi}

Çalıșmanın bu bölümünde analiz kapsamına alınan 5 bankanın TOPSIS yöntemi kullanılarak 2016-2018 yıllarına ilișkin performansları 
belirlenmiștir. TOPSIS yönteminin așamaları 2016, 2017 ve 2018 yılları için așağıdaki gibidir.

\section{Adım 1: Karar Matrisinin Olușturulması}

Karar matrisinin satırlarında birbirleriyle karșılaștırılan ve sıralanmak istenen katılım bankaları, sütunlarında ise değerlendirmede kullanılacak olan kriterler yer almaktadır. Çalıșmada 5 banka ve 8 değerlendirme kriteri yer almaktadır. Öncelikle $5 \times 8$ boyutlu standart karar matrisi olușturulmuștur.

Verileri incelenen bankaların 2016, 2017 ve 2018 yıllarına ait standart karar matrisleri Tablo 3, Tablo 4 ve Tablo 5 'te gösterilmiștir.

Tablo 3. 2016 Yilı Karar Matrisi (A)

\begin{tabular}{|l|c|c|c|c|c|c|c|c|}
\cline { 2 - 8 } \multicolumn{1}{c|}{} & O1 & 02 & 03 & 04 & 05 & O6 & 07 & 08 \\
\hline ALBARAKA & 6,93 & 66,49 & 3,66 & 26,19 & 0,66 & 9,54 & 1,98 & 47,47 \\
\hline KUVEYT & 8,06 & 58,61 & 2,29 & 34,57 & 1,11 & 13,85 & 2,38 & 50,53 \\
\hline FiNANS & 9,43 & 65,96 & 7,95 & 24,67 & 0,76 & 8,08 & 1,69 & 31,90 \\
\hline VAKIF & 18,71 & 62,93 & 1,31 & 34,28 & 0,40 & 2,16 & 1,59 & 54,87 \\
\hline ZíRAAT & 9,60 & 69,82 & 0,92 & 26,20 & 0,38 & 4,01 & 1,98 & 67,89 \\
\hline
\end{tabular}

Tablo 4. 2017 Yilı Karar Matrisi (A)

\begin{tabular}{|l|c|c|c|c|c|c|c|c|}
\cline { 2 - 8 } \multicolumn{1}{c|}{} & 01 & 02 & 03 & 04 & 05 & 06 & 07 & 08 \\
\hline ALBARAKA & 6,84 & 67,50 & 3,43 & 26,53 & 0,65 & 9,55 & 2,22 & 50,95 \\
\hline KUVEYT & 8,03 & 63,09 & 1,90 & 30,07 & 1,17 & 14,68 & 2,36 & 47,34 \\
\hline FiNANS & 10,39 & 64,83 & 9,12 & 25,93 & 0,96 & 9,24 & 2,22 & 45,48 \\
\hline VAKIF & 8,38 & 72,56 & 0,71 & 25,83 & 1,04 & 12,46 & 1,29 & 37,55 \\
\hline ZiRAAT & 9,78 & 79,26 & 0,91 & 17,04 & 1,10 & 11,32 & 2,45 & 72,37 \\
\hline
\end{tabular}

Tablo 5. 2018 Yilı Karar Matrisi (A)

\begin{tabular}{|l|c|c|c|c|c|c|c|c|}
\cline { 2 - 8 } \multicolumn{1}{c|}{} & 01 & 02 & 03 & 04 & 05 & 06 & 07 & 08 \\
\hline ALBARAKA & 0,08 & 62,02 & 3,09 & 29,02 & 0,32 & 4,11 & 0,98 & 244,35 \\
\hline KUVEYT & 0,07 & 61,79 & 1,29 & 23,23 & 1,17 & 15,99 & 1,58 & 103,94 \\
\hline
\end{tabular}




\begin{tabular}{|l|l|l|l|l|l|l|l|l|}
\hline FiNANS & 0,09 & 63,39 & 2,78 & 21,33 & 0,95 & 10,29 & 5,95 & 491,93 \\
\hline VAKIF & 0,07 & 64,36 & 1,37 & 26,39 & 1,55 & 21,31 & 1,98 & 100,20 \\
\hline ZiRAAT & 0,10 & 79,95 & 0,25 & 12,60 & 1,45 & 14,54 & 2,32 & 124,19 \\
\hline
\end{tabular}

Adım 2: Normalize Edilmiș Karar Matrisinin Olușturulması (R)

Her yıl için normalize karar matrisi, karar matrisi sütunlarının her bir değerinin ilgi kareleri toplamının kareköküne bölünüp kriterlerinin farklı ölçütleri ya da oranları ortadan kaldırması ve tek paydaya dönüștürme suretiyle bulunur. Normalize edilmiș karar matrislerinin 2016, 2017 ve 2018 yıllarına göre olușturulan tabloları așağıda gösterilmiștir.

Tablo 6. 2016 Yilı Standart Karar Matrisi (R)

\begin{tabular}{|l|c|c|c|c|c|c|c|c|}
\cline { 2 - 8 } \multicolumn{1}{c|}{} & 01 & 02 & 03 & 04 & 05 & 06 & 07 & 08 \\
\hline ALBARAKA & 0,273 & 0,458 & 0,398 & 0,397 & 0,413 & 0,497 & 0,456 & 0,409 \\
\hline KUVEYT & 0,318 & 0,404 & 0,249 & 0,524 & 0,695 & 0,721 & 0,548 & 0,436 \\
\hline FiNANS & 0,372 & 0,455 & 0,865 & 0,374 & 0,476 & 0,421 & 0,389 & 0,275 \\
\hline VAKIF & 0,737 & 0,434 & 0,143 & 0,520 & 0,251 & 0,112 & 0,366 & 0,473 \\
\hline ZiRAAT & 0,378 & 0,481 & 0,100 & 0,397 & 0,238 & 0,209 & 0,456 & 0,586 \\
\hline
\end{tabular}

Tablo 7. 2017 Yilı Standart Karar Matrisi (R)

\begin{tabular}{|l|c|c|c|c|c|c|c|c|}
\cline { 2 - 9 } \multicolumn{1}{c|}{} & 01 & 02 & 03 & 04 & 05 & 06 & 07 & 08 \\
\hline \multirow{2}{*}{$\begin{array}{l}\text { ALBARAKA } \\
\text { KUVEYT }\end{array}$} & 0,349 & 0,433 & 0,343 & 0,466 & 0,291 & 0,367 & 0,462 & 0,438 \\
\cline { 2 - 9 } & 0,409 & 0,405 & 0,190 & 0,528 & 0,523 & 0,565 & 0,491 & 0,407 \\
\cline { 2 - 9 } $\begin{array}{l}\text { FiNANS } \\
\text { VAKIF }\end{array}$ & 0,529 & 0,416 & 0,913 & 0,456 & 0,429 & 0,356 & 0,462 & 0,391 \\
\cline { 2 - 9 } & 0,427 & 0,466 & 0,071 & 0,454 & 0,465 & 0,479 & 0,268 & 0,323 \\
\cline { 2 - 9 } & 0,498 & 0,509 & 0,091 & 0,299 & 0,492 & 0,436 & 0,510 & 0,622 \\
\hline
\end{tabular}

Tablo 8. 2018 Yilı Standart Karar Matrisi (R)

\begin{tabular}{|l|c|c|c|c|c|c|c|c|}
\cline { 2 - 8 } \multicolumn{1}{c|}{} & 01 & 02 & 03 & 04 & 05 & 06 & 07 & 08 \\
\hline ALBARAKA & 0,432 & 0,416 & 0,676 & 0,559 & 0,122 & 0,127 & 0,141 & 0,420 \\
\hline KUVEYT & 0,378 & 0,415 & 0,282 & 0,448 & 0,446 & 0,495 & 0,228 & 0,179 \\
\hline FiNANS & 0,486 & 0,425 & 0,608 & 0,411 & 0,362 & 0,318 & 0,857 & 0,846 \\
\hline VAKIF & 0,378 & 0,432 & 0,300 & 0,509 & 0,591 & 0,660 & 0,285 & 0,172 \\
\hline ZiRAAT & 0,540 & 0,536 & 0,055 & 0,243 & 0,553 & 0,450 & 0,334 & 0,214 \\
\hline
\end{tabular}




\section{Adım 3: Ağırlıkıı Standart Karar Matrisinin Olușturulması (V)}

Bu adımda değerlendirme faktörlerine bağlı ağırlık değerleri $w_{\text {. }}$ belirlenmiștir. Daha sonra bir önceki adımda hesaplanmıș olan normalize edilmiș değerler, $w_{i}$ değerleri ile çarpılarak ağırlıklandıııımıș normalize edilmiș değerlere ulașılmıștır. Bu adımda hesaplanan ağırlıklı standart karar matrisleri Tablo 9, Tablo 10 ve Tablo 11 'de gösterilmektedir.

Tablo 9. 2016 Yılı Ağırlıklı Standart Karar Matrisi (V)

\begin{tabular}{|l|c|c|c|c|c|c|c|c|}
\hline & 01 & 02 & 03 & 04 & 05 & 06 & 07 & 08 \\
\hline ALBARAKA & 0,0273 & 0,0458 & 0,0398 & 0,0397 & 0,0620 & 0,0745 & 0,0683 & 0,0614 \\
\hline KUVEYT & 0,0318 & 0,0404 & 0,0249 & 0,0524 & 0,1043 & 0,1082 & 0,0821 & 0,0654 \\
\hline FiNANS & 0,0372 & 0,0455 & 0,0865 & 0,0374 & 0,0714 & 0,0631 & 0,0583 & 0,0413 \\
\hline VAKIF & 0,0737 & 0,0434 & 0,0143 & 0,0520 & 0,0376 & 0,0169 & 0,0549 & 0,0710 \\
\hline ZiRAAT & 0,0378 & 0,0481 & 0,0100 & 0,0397 & 0,0357 & 0,0313 & 0,0683 & 0,0878 \\
\hline
\end{tabular}

Tablo 10. 2017 Yılı Ağırlıklı Standart Karar Matrisi (V)

\begin{tabular}{|l|c|c|c|c|c|c|c|c|}
\cline { 2 - 8 } \multicolumn{1}{c|}{} & 01 & 02 & 03 & 04 & 05 & 06 & 07 & 08 \\
\hline ALBARAKA & 0,0349 & 0,0433 & 0,0343 & 0,0466 & 0,0436 & 0,0551 & 0,0693 & 0,0656 \\
\hline KUVEYT & 0,0409 & 0,0405 & 0,0190 & 0,0528 & 0,0784 & 0,0847 & 0,0737 & 0,0610 \\
\hline FiNANS & 0,0529 & 0,0416 & 0,0913 & 0,0456 & 0,0644 & 0,0533 & 0,0693 & 0,0586 \\
\hline VAKIF & 0,0427 & 0,0466 & 0,0071 & 0,0454 & 0,0697 & 0,0719 & 0,0403 & 0,0484 \\
\hline ZíRAAT & 0,0498 & 0,0509 & 0,0091 & 0,0299 & 0,0738 & 0,0653 & 0,0765 & 0,0932 \\
\hline
\end{tabular}

Tablo 11. 2018 Yılı Ağırlıklı Standart Karar Matrisi (V)

\begin{tabular}{|l|l|l|l|l|l|l|l|l|}
\hline & O1 & O2 & 03 & O4 & 05 & 06 & 07 & 08 \\
\hline ALBARAKA & 0,0432 & 0,0416 & 0,0676 & 0,0559 & 0,0183 & 0,0191 & 0,0212 & 0,0630 \\
\hline KUVEYT & 0,0378 & 0,0415 & 0,0282 & 0,0448 & 0,0669 & 0,0742 & 0,0342 & 0,0268 \\
\hline FiNANS & 0,0486 & 0,0425 & 0,0608 & 0,0411 & 0,0543 & 0,0478 & 0,1286 & 0,1269 \\
\hline VAKIF & 0,0378 & 0,0432 & 0,0300 & 0,0509 & 0,0886 & 0,0989 & 0,0428 & 0,0259 \\
\hline ZiRAAT & 0,0540 & 0,0536 & 0,0055 & 0,0243 & 0,0829 & 0,0675 & 0,0501 & 0,0320 \\
\hline
\end{tabular}




\section{Adım 4: Ideal ( ) ve Negatif İdeal () Çözümlerin Olușturulması}

Bu adımda, İdeal $A^{+}$ve negatif ideal $A^{-}$den olușan çözüm kümeleri olușturulmaktadır. $A^{+}$seti $\bigvee$ matrisinin her sütundaki en büyük değeriyle, $A$ seti $\bigvee$ matrisindeki her sütununun en küçük değeri ile seçilmiștir. 2016, 2017 ve 2018 yılları için İdeal $A^{+}$ve Negatif İdeal A- kümeleri așağıda gösterilmiștir.

2016 yılı için İdeal $A^{+}$ve Negatif İdeal $A^{-}$kümeleri;

$A^{+}=(0,0737 ; 0,0481 ; 0,0865 ; 0,0524 ; 0,1043 ; 0,1082 ; 0,0821 ; 0,0878)$

$A^{-}=(0,0273 ; 0,0404 ; 0,0100 ; 0,0374 ; 0,0357 ; 0,0169 ; 0,0549 ; 0,0413)$

2017 yılı için İdeal $A^{+}$ve Negatif İdeal $A^{-}$kümeleri;

$A^{+}=(0,0529 ; 0,0509 ; 0,0913 ; 0,0528 ; 0,0784 ; 0,0847 ; 0,0765 ; 0,0932)$

$A^{-}=(0,0349 ; 0,0405 ; 0,0071 ; 0,0299 ; 0,0436 ; 0,0533 ; 0,0403 ; 0,0484)$

2018 yılı için İdeal $A^{+}$ve Negatif İdeal $A^{-}$kümeleri;

$A^{+}=(0,0540 ; 0,0536 ; 0,0676 ; 0,0559 ; 0,0886 ; 0,0989 ; 0,1286 ; 0,1269)$

$A^{-}=(0,0378 ; 0,0415 ; 0,0055 ; 0,0243 ; 0,0183 ; 0,0191 ; 0,0212 ; 0,0259)$

\section{Adım 5: Ayırım Kriterlerinin Hesaplanması}

Bu adımda, her alternatifinin pozitif ideal çözümden uzaklığı $\left(S^{+}\right)$ ve negatif ideal çözümden uzaklığı (S-) hesaplanmıștır. Bu adımda bulunan sonuçlar șöyle gösterilmiștir;

2016 yılı için $S^{+}$ve S- kümeleri;

$S^{+}=(0,0912 ; 0,0782 ; 0,0861 ; 0,1380 ; 0,1346)$

$S=(0,0716 ; 0,1194 ; 0,0970 ; 0,0490 ; 0,0238)$

2017 yılı için S+ ve S- kümeleri;

$S^{+}=(0,0811 ; 0,0807 ; 0,0507 ; 0,1040 ; 0,0876)$

$S=(0,0433 ; 0,0634 ; 0,0945 ; 0,0370 ; 0,0520)$ 
2018 yılı için S+ ve S- kümeleri;

$S^{+}=(0,1649 ; 0,1487 ; 0,0649 ; 0,1393 ; 0,1451)$

$S=(0,0700 ; 0,0807 ; 0,1309 ; 0,1145 ; 0,0882)$

\section{Adım 6: İdeal Çözüme Göreli Yakınlığın Hesaplanması}

İdeal çözüme yakınlığı $\left(C_{i}^{*}\right)$, önceden belirlenen TOPSIS yönteminin alııncı adım denklemi kullanılarak bütün bankalar için teker teker hesaplanmıștır.

2016 yılı için $C_{i}^{*}$ değerleri;

$C_{i}^{*}=(0,4397 ; 0,6041 ; 0,5296 ; 0,2618 ; 0,1502)$

2017 yılı için $C_{i}^{*}$ değerleri;

$C_{i}^{*}=(0,3481 ; 0,4399 ; 0,6506 ; 0,2621 ; 0,3723)$

2018 yılı için $C_{i}^{*}$ değerleri;

$C_{i}^{*}=(0,2978 ; 0,3518 ; 0,6685 ; 0,4511 ; 0,3780)$

Bu adımlardan hareketle bankaların 2016, 2017 ve 2018 yıllarına ilișkin performans değerleri ve sıralamaları Tablo 12'deki gibidir.

Tablo 12. Bankaların Performans Değerleri ve Sıralamaları

\begin{tabular}{|l|c|c|c|c|c|c|}
\hline & \multicolumn{2}{|c|}{2016} & \multicolumn{2}{c|}{2017} & \multicolumn{2}{c|}{2018} \\
\hline \multirow{2}{*}{ Banka Kodu } & $\begin{array}{c}C_{i}^{*} \\
\text { Değeri }\end{array}$ & Sıralama & $\begin{array}{c}C_{i}^{*} \text { De- } \\
\text { ğeri }\end{array}$ & Sıralama & $\begin{array}{c}C_{i}^{*} \text { De- } \\
\text { ğeri }\end{array}$ & Sıralama \\
\hline ALBARAKA & 0,4397 & 3 & 0,3481 & 4 & 0,2978 & 5 \\
\hline KUVEYT & 0,6041 & 1 & 0,4399 & 2 & 0,3518 & 4 \\
\hline FiNANS & 0,5296 & 2 & 0,6506 & 1 & 0,6685 & 1 \\
\hline VAKIF & 0,2618 & 4 & 0,2621 & 5 & 0,4511 & 2 \\
\hline ZíRAAT & 0,1502 & 5 & 0,3723 & 3 & 0,3780 & 3 \\
\hline
\end{tabular}

Tablo 12'de görüldüğü üzere, TOPSIS yöntemi kullanılarak 2016 yılında hesaplanan değerler doğrultusunda Kuveył Türk Katılım Bankası A.Ș. finansal performansı en yüksek olan banka'dır. Bu bankayı sırasıyla Türkiye Finans Katılım Bankası A.Ș. ve Albaraka Türk Katılım Bankası A.Ș. takip etmiștir. 2016 yılının en düșük finansal performansa sahip 
bankaları ise Ziraat Katılım Bankası A.Ș. ve Vakıf Katılım Bankası A.Ș. olmuștur.

2017 yılı için hesaplanan TOPSIS değerleri doğrultusunda Türkiye Finans Katılım Bankası A.Ș. finansal performansı en yüksek banka olurken, onu Kuveyt Türk Katılım Bankası A.Ș.ve Ziraat Katılım Bankası A.Ș. takip etmiș̦ir. 2017 yılının en düșük finansal performansa sahip bankaları ise Vakıf Katılım Bankası A.Ș. ve Albaraka Türk Katılım Bankası A.Ș. olmuștur.

TOPSIS yöntemi kullanılarak hesaplanan 2018 yılı değerlerine göre, Türkiye Finans Katılım Bankası A.Ș. finansal performansı en yüksek banka olurken, onu Vakıf Katılım Bankası A.Ș. ve Ziraat Katılım Bankası A.Ș. takip etmiștir. Aynı yılın en düșük finansal performansa sahip bankaları ise Albaraka Türk Katılım Bankası A.Ș. ve Kuveył Türk Katılım Bankası A.Ș. olmuștur. 2018 yılı TOPSIS sonuçlarına göre, Albaraka Türk Katılım Bankası A.Ș. ve Kuveyt Türk Katılım Bankası A.Ș. ise en düșük finansal performansa sahip olan bankalardır.

2016-2018 yılları arasında bankaların ortalama performans değerleri ve sıralamaları, Tablo 13'de görülmektedir.

Tablo 13. Ortalama Performans Değerleri ve Sıralamaları

\begin{tabular}{|c|l|c|c|}
\hline S.No & Banka Kodu & Ortalama Değerler & 3 Yıllık Performans Sırası \\
\hline $\mathbf{1}$ & ALBARAKA & 0,3619 & 3 \\
\hline $\mathbf{2}$ & KUVEYT & 0,4653 & $\mathbf{2}$ \\
\hline $\mathbf{3}$ & FINANS & 0,6162 & 1 \\
\hline $\mathbf{4}$ & VAKIF & 0,3250 & 4 \\
\hline $\mathbf{5}$ & ZIRAAT & 0,3002 & 5 \\
\hline
\end{tabular}

Sektörde faaliyet gösteren bankaların 3 yıllık ortalama performans değerlerine göre sıralamaları Tablo 13'de gösterilmektedir. Ortalama değer sonuçlarına göre, en bașarılı ilk üç bankanın sırası ile Türkiye Finans Katılım Bankası A.Ș., Kuveył Türk Katılım Bankası A.Ș.ve Albaraka Türk Katılım Bankası A.Ș. olduğu tespit edilmiștir.

TOPSIS yönteminde elde edilen sonuçlar, negatif ideal ve pozitif ideal değere göre yorumlanmaktadır. 0,50'nin üzerindeki değerler pozitif ideale alındaki değerler ise negatif ideale yakınlaștırmaktadır. Pozitif idealin 1 ve negatif idealin 0 olduğu modelde, değer 1'e yakınlaștıkça sektörde ulașılmak istenen, yatırım ve finansman kararlarının doğru verildiği ișletme konumuna ulașıldığını gösterir. Değerin 0 ya da 
yakın olduğu durumlar, yönetimin finansal performansının yetersiz olduğu, yatırım ve finansman kararlarında rasyonellikten uzaklașıldığını göstermektedir. Buna göre ortalama performans değerleri baz alındığında, 1 bankanın 0,50'nin üzerinde TOPSIS değeri alarak pozitif ideale yakın, 4 bankanın ise 0,50'nin alıında değer alarak negatif ideale yakın performans sergiledikleri tespit edilmiștir. Bankalar arasında Türkiye Finans Katılım Bankası A.Ș., ortalama 0,6162 puan ile en iyi performans sergileyen banka olurken, 0,3002 puan ile Ziraat Katılım Bankası A.Ș. en düșük performans gösteren banka olmuștur.

\section{Sonuç}

Türk bankacılık sektöründe önemli bir paya sahip olan katılım bankaları, son yıllarda bankacılık sektörünün üzerinde bir büyüme gerçekleștirmișlerdir. Türk ekonomisinin ihtiyacı olan ürün ve hizmetleri sunarak finansal sistemin gelișmesine katkı sağlayan katılım bankaları, diğer taraftan reel sektörün büyümesine de yardımcı olmaktadırlar (Pehlivan, 2016, s. 319-320).

2018 yılında Türkiye'de katılım bankacılık sektörü Türkiye Katılım Bankaları Birliği alında faaliyet gösteren Albaraka Türk, Kuveyt Türk, Türkiye Finans, Vakıf Katılım ve Ziraat Katılım bankalarından olușmaktadır. Katılım bankaları Türk bankacılık sektörü içerisinde her geçen yıl daha bașarılı bir seyir izleyerek hem büyümeye hem de sektörden aldıkları payı artırmaya devam etmektedirler. 2018 yılı verileri ıșığında bankacılık piyasasından aldığı pay aktif büyüklüğünde \%5,3 kullandırılan fonlarda \%5, 1 ve toplanan fonlarda \%6,7'ye yükselmiștir.

Son yıllarda İslami bankaların sadece İslam ülkeleri ile sınırlı kalmaksızın tüm dünyada artan bir öneme sahip olması akademik çalıșmalarda bu bankalar üzerine yapılan araștırmaların artıș göstermesine sebep olmuștur. Konunun artan önemi göz önüne alınarak bu çalıșmada, TOPSIS yöntemi kullanılarak Türkiye'de faaliyet gösteren 5 bankaya ait 2016-2018 dönemi finansal tablolarından alınan oranlar kullanılarak, bankaların yıllar itibariyle birbirlerine göre performans değerlendirmeleri yapılmıștır. Bankaların performans değerlemesinde, 8 finansal oran kullanılmıștır.

TOPSIS yönteminde, pozitif ve negatif ideal puanlara göre değerlendirme yapılmaktadır. Pozitif idealin 1, negatif idealin 0 olduğu modelde, 0,50'nin üzerindeki puanlar pozitif ideale yakın, altındaki puanlarda negatif ideale yakın olarak değerlendirilmektedir. Yapılan 
değerlendirme sonucunda finansal performans açısından ilk üç banka; QNB Finansbank A.Ș., Kuveył Türk Katılım Bankası A.Ș. ve Albaraka Türk Katılım Bankası A.Ș. olarak gerçekleșmiștir. Sıralamada, Ziraat Katılım Bankası A.Ș. düșük finansal performans sergilemiștir. Beș banka arasından puanı pozitif ideale yakın olan banka QNB Finansbank A.Ș.'dir. Pozitif ideale yakınlık değerine göre QNB Finansbank A.Ș. yatırım ve finansman kararlarında örnek alınabilecek bankalar olarak değerlendirilebilir.

Çalıșmada, finansal oranlar olarak Özkaynaklar / Toplam Aktifler, Toplam Krediler ve Alacaklar / Toplam Aktifler, Duran Aktifler / Toplam Aktifler, Likit Aktifler / Toplam Aktifler, Ortalama Aktif Karlılığı, Ortalama Özkaynak Karlılı̆ı̆, Özel Karșılıklar Sonrası Net kar payı / Toplam Aktifler, Özel Karșılıklar Sonrası Net kar payı / Toplam Faaliyet Gelirleri oranları kullanılmıștır. Söz konusu oranlar düșünüldüğünde, ișletmeler finansal performanslarını artırabilmek için likitide karlılık seviyelerini artırıp varlıklarını da verimli kullanmalıdırlar. Performansı düșük ișletmelerin, ellerindeki mevcut varlıkları etkin bir șekilde kullanarak karlılıklarını artırma yoluna gitmeleri pozitif ideale yaklașmalarına ve performanslarının artmasına katkı sağlayacaktır.

Bu çalıșmada 8 finansal oran kullanılarak TOPSIS yöntemi ile Türk katııım bankalarının finansal performansları değerlendirilmiștir. Yapılacak yeni araștırmalarda, kullanılan finansal oranlar ile yöntem farklılaștırılarak ilgili sektörde finansal performans değerlemesi gerçekleștirilebilir. 


\section{KAYNAKCุA}

Abdi, Y. H. (2018). Türkiye'de Faaliyet Gösteren İslami Bankaların Çok Kriterli Karar Verme Yöntemlerine Göre Etkinlik ve Verimlilik Açısından İncelenmesi. (Yayımlanmamıș Yüksek Lisans Yeterlik Tezi). Eskișehir: Anadolu Üniversitesi Sosyal Bilimler Enstitüsü.

Alsu, E., Tașdemir, A. ve Kallo, Z. (2018). Katılım Bankalarının Performanslarının Değerlendirilmesi: TOPSIS Yöntemi ile Uluslararası Karșılaștırma. Gaziantep University Journal of Social Sciences, 17(1), 303-315.

Cağlıyan, V., Ömürbek, N. Karaatlı, M. Ișıklar, Z. (2015). Determination Of Profitability Performances Of Industrial Sectors By Means of TOPSIS Method Application of Turkey. European Scientific Journal, 1, 43-53.

Esmer, Y. ve Bağcı, H. (2016). Katılım Bankalarında Finansal Performans Analizi: Türkiye Örneği. Mehmet Akif Ersoy Üniversitesi Sosyal Bilimler Enstitüsü Dergisi, 8(15), 17-30.

Kendirli, H., Kendirli, S. ve Aydın, Y. (2019). Küresel Kriz Çerçevesinde Katılım Bankalarının ve Ticari Bankaların Mali Performanslarının TOPSIS Yöntemiyle Analizi. Atatürk Üniversitesi İktisadi ve İdari Bilimler Dergisi, 33(1), 137-153.

Pehlivan, P. (2016). Türkiye'de Katılım Bankacılığı ve Bankacılık Sektöründeki Önemi. Selçuk Üniversitesi IïBF Sosyal Ekonomik Araștırmalar Dergisi, 16(31), 296 - 324.

Șamiloğlu, F., Tükenmez, N. M. ve Bağcı, H. (2013). Ticari Bankalar İle Katılım Bankalarının Karlılık Performanslarının TOPSIS Yöntemi İle Karșılaștırılması, 17.Finans Sempozyumu, Muğla, 23-26 Ekim, 263-280.

TKBB (2018). Katılım Bankaları. İstanbul: TKBB Yayınları.

Wanke, P., Azad, M. A. K., ve Barros, C. P. (2016). Predicting Efficiency in Malaysian Islamic Banks: A Two-Stage TOPSIS and Neural Networks Approach. Research in International Business and Finance, 36, 485-498.

Wu, C. R., Lin C. T. ve Tsai, P. H., (2008). Financial Service of Wealth Management Banking: Balanced Scorecard Approach. Journal of Social Sciences, 4 (4), 255 263.

Yayar, R. ve Baykara, H. (2012). TOPSIS Yöntemi ile Katılım Bankalarının Etkinliği ve Verimliliği Üzerine Bir Uygulama. Business and Economics Research Journal, 3(4), 21-42. 